IRSH 63 (2018), Special Issue, pp. 2 I I-23 I doi:I0.1017/S002085901 8000299 (C) 2018 Internationaal Instituut voor Sociale Geschiedenis

\title{
The "Other" at Home: Deportation and Transportation of Libyans to Italy During the Colonial Era (19I I-I943)*
}

\author{
Francesca Di Pasquale \\ Soprintendenza archivistica per la Sicilia \\ Archivio di Stato di Palermo Via Vittorio Emanuele 3 I \\ 90133, Palermo, Italy* \\ E-mail: francesca.dipasquale76@gmail.com
}

\begin{abstract}
This article analyses the practices of deportation and transportation of colonial subjects from Libya, Italy's former possession, to the metropole throughout the entire colonial period (I9I I-I943). For the most part, the other colonial powers did not transport colonial subjects to Europe. Analysing the history of the punitive relocations of Libyans, this article addresses the ways in which the Italian case may be considered peculiar. It highlights the overlapping of the penal system and military practices and emphasizes the difficult dialogue between "centre" and "periphery" concerning security issues inside the colony. Finally, it focuses on the experience of the Libyans in Italy and shows how the presence there of colonial subjects in some respects overturned the "colonial situation", undermining the relationship of power between Italians and North Africans.
\end{abstract}

\section{INTRODUCTION}

On 23 October I9 I I, just twenty days after Italian troops landed in Tripoli, a massive revolt surprised the colonial soldiers in the Shara al-Shatt oasis, just outside the city. The Italians had come to Libya ${ }^{\mathrm{I}}$ certain of easy victory, convinced that the native population would rise up against the Turks. As a result of the revolt, the Italians in Tripoli suddenly realized that they had wrongly evaluated the colonial venture: after they had landed, the Arabs formed a coalition with the Turks and organized a common resistance to Italian occupation. Italian soldiers, caught off guard, reacted with brutality. An unspecified number of Arabs were shot in the hours following

\footnotetext{
* The research for this article is part of the project "Four Centuries of Labour Camps: War, Rehabilitation, Ethnicity", directed by the International Institute of Social History (IISH) and the Netherlands Institute for War, Holocaust and Genocide Studies (NIOD), and funded by the Netherlands Organization for Scientific Research (NWO).

I. Libya was then constituted by the Turkish-Ottoman provinces of Tripolitania and Cyrenaica.
} 
the revolt. ${ }^{2}$ Giovanni Giolitti, Italy's Prime Minister, ordered the immediate deportation to Italy of all "arrested rioters". 3 This deportation, which might have seemed like an exceptional measure connected to the gravity of the situation, marked the start of an enduring period of deportations and transportations of Libyans to Italy, which lasted until the end of the Italian colonial occupation of Libya in I 943. In fact, the forced removal of Libyans was not merely a corollary of the Italian colonizer's repressive measures, but an integral part of the colonial punitive system. In particular, the deportation of Libyans who had not been tried and the transportation of convicts became standard practice in managing the colony from I9I I to the I930s. ${ }^{4}$

The deportation of Libyans was not the first case of Italian repressive practice in its colonial possessions. Italian colonialism developed firstly in Eastern Africa, with the invasion of Eritrea (I890-I94I) and Somalia (I 892-I94I), thereafter in North Africa, with the military occupation of Libya (I9I I-I943). Finally, with the conquest of Ethiopia in I935, the Fascist regime proclaimed the birth of the Italian Empire, which collapsed a few years later, during World War II..$^{5}$ Between I 886 and I 892, when Italy took its first steps in Eritrea, military authorities ordered the transfer to Italy of a hundred people of different origins. ${ }^{6}$ In 1937, deportation measures struck again against natives from Italian East Africa. As part of the harsh repression that followed the attack on Viceroy Rodolfo Graziani, Governor in Ethiopia, the colonial government ordered the confinement in Italy of some 400 Ethiopians. ${ }^{7}$

Both in terms of the number of subjects involved and its long duration, the transfer of Libyans to Italy was the most significant deportation of colonial subjects in Italian colonial history. The reasons why the colonial authorities resorted to deportation in Libya more often than in the case of other Italian possessions still need to be clarified. In general, this issue is connected to the prison systems in each colony and, in particular, to the question of whether there were sites suitable to confine subjects considered harmful for the colony's security. In Eritrea, Nocra performed this role, with Eritrean subjects previously deported to Italy also being transferred to

2. Regarding the first month of the Italian occupation of Libya and the Shara al-Shatt revolt, see Angelo Del Boca, Gli italiani in Libia, 2 vols (Milan, 2013), I, pp. 96-1 36.

3. Telegram from Giolitti to Caneva, Commander-in-Chief in Tripoli, 24 October 191 I, in Archivio Centrale dello Stato, Rome [hereafter, ACS], Carte Giolitti, folder 22, file 57.

4. Nicola Labanca, La guerra italiana per la Libia (I9I I-I93I) (Bologna, 20I2), p. 70.

5. For a general overview of Italian colonialism, see idem, Oltremare. Storia dell'espansione coloniale italiana (Bologna, 2002).

6. The deportees came from Eritrea, Ethiopia, Sudan, Somalia, Arab jazira, and also from Greece, as part of the Ottoman Empire. See Marco Lenci, "Prove di repressione. Deportati eritrei in Italia (I 886-I893)", Africa, I (2003), pp. I-34, 7-8.

7. Paolo Borruso, L'Africa al confino. La deportazione etiopica in Italia (1937-39) (Manduria, 2003). 
this prison-island. As I will explain later, Italian authorities made little use of the other option open to their counterparts in other empires, namely intercolonial deportation/transportation, i.e. the possibility to transport Libyan convicts to, say, Nocra in Eritrea.

The Italian case is largely out of step with the policy regarding deportation and transportation enacted by the other European colonial powers. The history of Italian deportation and transportation chiefly concerns colonial subjects, who were transferred from colonies to the metropole. The other colonial powers in most cases resorted to penal transportation in order to remove metropolitan convicts, transferring them from the metropole to the colonies. For the most part, colonized subjects were transported to other colonial possessions. ${ }^{8}$ The only exceptions to this were found in the French Empire. Indeed, following anti-imperial revolts, some Algerians were transferred to southern France in the nineteenth century.9 ${ }^{9}$ The internment of Algerians in France decreased and finally ended when the French army succeeded in repressing the revolts. As I will explain later, the nexus between the control over the colony and the transfer of Libyans is also the key to understanding the forced removal of colonial subjects to Italy. Nevertheless, unlike the French deportations, the coerced transfers of Libyans to Italy lasted the entire colonial period, from I9I I to I943.

This article addresses in what way the Italian case may be considered peculiar. Specifically, it analyses the practices of deportation and transportation from Libya to Italy within the imperial landscape of the twentieth century. Even if exceptional, the analysis of the Italian case integrates the study of the general theme of this volume, namely punitive relocations from a colonial perspective, and from a double viewpoint. On the one hand, it was left to the colonial "periphery" to decide whether to transfer Libyan subjects to Italy. On the other, the choice of whether to confine the majority of the prisoners in the south of Italy also originated from the "colonial" view of the southern regions, as I will explain later.

The first part of this article presents a general sketch of the deportation and transportation of Libyans. Highlighting the overlapping of the penal

8. For the general framework of penal transportation in Western empires, see Clare Anderson and Hamish Maxwell-Stewart, "Convict Labour and the Western Empires, I4 I 5-1954", in R. Aldrich and K. McKenzie (eds), The Routledge History of Western Empires (London [etc.], 2014), pp. 102I 17. For two of the most important historical instances of penal transportation, British India and French Guiana, see Clare Anderson, "Sepoys, Servants and Settlers: Convict Transportation in the Indian Ocean, I787-1945", in F. Dikötter and I. Brown (eds), Cultures of Confinement: A History of the Prison in Africa, Asia, and Latin America (New York, 2007), pp. I 8 5-220; Danielle DonetVincent, De soleil et de silences. Histoire des bagnes de Guyane (Paris, 2003); Michel Pierre, Bagnards. La terre de la grand punition, Cayenne I852-1953 (Paris, 2000); Peter Redfield, Space in the Tropics: From Convicts to Rockets in French Guiana (Berkeley, CA [etc.], 2000).

9. Sylvie Thénault, L'Algérie, une colonie aux marges de l'archipel punitif, available at http:// convictvoyages.org/expert-essays/lalgerie; last accessed I9 January 2018. 
system and military practices, here I emphasize the difficult dialogue between "centre" and "periphery" concerning security issues inside the colony. The second part focuses on the experience of the Libyans in Italy. The expulsions of the Libyans from their native soil aimed foremost to tame the resistance movements against the colonizer. But the presence of colonial subjects in Italy also entailed different outcomes to those which the Italian authorities had foreseen, including the upturning of the roles of Italians and Libyans, which subverted the colonial relationship of power.

\section{DEPORTATION AND PENAL TRANSPORTATION WITHIN THE ITALIAN COLONIAL SYSTEM}

We can divide the forced removal of Libyans to Italy into roughly three categories: collective deportations following serious military defeats for the Italian army; individual deportations of political dissidents or of supposed opponents; and transportation of convicts already detained in colonial prisons. ${ }^{10}$

It is difficult to establish a clear-cut division between deportations as administrative measures and deportations for political reasons. The latter were implemented over the entire colonial period; they were intended to strike against "rebels" or potential "rebels", i.e. both combatants and political figures whose presence in Libya could undermine Italian authority. Deportation was frequently ordered on the basis of very generic accusations or the mere suspicion that someone represented a potential threat. The Libyans deported for political reasons also included people acquitted by colonial courts or who had already served a term of imprisonment in Libya, but whom military authorities judged dangerous to the security of the colony. ${ }^{\text {II }}$ The implementation of this measure has to be set in the context of Italy's "native policy" in Libya. ${ }^{\mathrm{I} 2}$ At times, certain notables were exiled as part of the so-called chiefs policy, i.e. the alliances established between the colonial authorities and some figures within the Libyan political leadership.

The lack of lists of subjects who left Libya, and the fact that an unspecified number of people died during the crossings, makes it difficult to

Io. Since they were connected with the political appraisal by the colonial authorities, transportations and deportations had an undetermined duration.

I I. Simone Bernini, "Documenti sulla repressione italiana in Libia agli inizi della colonizzazione (I9I I-I9I 8)", in Nicola Labanca (ed.), Un nodo. Immagini e documenti sulla repressione coloniale italiana in Libia (Manduria, 2002), p. I4 I.

I 2. The same pattern also characterized Italy's native policy in Eritrea. See Antonio M. Morone, "Istituzioni, fra assimilazione e amministrazione indiretta", in Gian Paolo Calchi Novati (ed.), Il colonialismo italiano e l'Africa (Rome, 20I I), pp. 213-235; and Isabella Rosoni, La colonia eritrea. La prima amministrazione coloniale italiana (I880-I9I2) (Macerata, 2006). 
estimate the exact number of Libyan deportees in Italy during the colonial era. According to the Libyan Studies Centre, ${ }^{\mathrm{I}}{ }^{14}$ the Italian authorities deported about 5,000-6,000 Libyans to Italy. ${ }^{\text {I4 }}$ The scholar Mario Missori estimates that there were 4,000 deportees in Italy between I 9I I and I918. ${ }^{\text {Is }}$ All things considered, we can state with some confidence that, after World War I, deportation no longer involved large groups of subjects, but mainly individuals: notables or leading figures of the resistance movement. ${ }^{16}$

The main reason for collective deportations was the attempt to clear out the territory that had been the theatre of revolts and to expel as many people as possible. This happened at the beginning of the colonial occupation, after the above-mentioned Shara al-Shatt revolt, and in I9I s, after the battle of Qardabiah, during the "great Arabic revolt", which forced the Italians to retreat to a few coastal outposts. Undoubtedly, deportation aimed to intimidate the colonial population. In particular, in I9I I and in I9I 2, the decision to deport did not correspond to any real individualized appraisal of the dangerousness of the subjects involved. After the military disaster in Adowa (Ethiopia) in I896 - which was the most serious military defeat for any European army during the imperial age - the Italian government needed to hide the military difficulties that Italy was encountering in Libya from other European colonial powers. ${ }^{17}$ After the Shara al-Shatt revolt, in order to stop the massacres of Libyans by Italian soldiers, which were a clear indication of the weakness of the colonial army, Giolitti, the prime minister, ordered deportations. The arrests were made en masse, which is why beggars, labourers, peasants, wealthy owners, and storekeepers were all

I3. "Libyan Studies Centre" is the name with which the Libyan Jehad Centre for Historical Studies was known abroad. It was founded in 1978 to foster studies on Libyan history and in particular on the Libyan resistance (jibad in Arabic) to the Italian colonizer (see the Centre's website (in Arabic) at http://libsc.org.ly/mrkaz/; last accessed i 9 January 20r 8). Between $200 \mathrm{I}$ and 2005, the Libyan Centre and the Istituto Italiano per l'Africa e l'Oriente (Italian Institute for Africa and the East) directed a research project focused mainly on the Libyan deportees in Italy during the colonial era.

I4. Libyan Jehad Centre for Historical Studies, Information Bulletin No. I (undated, but probably I990s). Nicola Labanca also reports the same figure. See Labanca, La guerra italiana per la Libia, p. 7 I.

I 5. Mario Missori, "Una ricerca sui deportati libici nelle carte dell'Archivio centrale dello Stato", in Fonti e problemi della Politica Coloniale italiana, Atti del convegno, Taormina-Messina, 23-29 ottobre 1989, 2 vols (Rome, I996), I, pp. 253-258.

16. These figures do not include about 5,000 Libyans transferred to two Sicilian villages, Floridia and Canicattini Bagni (Syracuse) in I9 I 5 . We will discuss this group of Libyans later.

17. Giolitti's concern emerges clearly from the first telegrams he sent to Caneva after the Shara alShatt revolt. In particular, Giolitti asked for precise news about what happened and the number of deaths, in order to avoid the "discredit" of Italy, both within and outside the country. See ACS, Carte Giolitti, folder 22, file 57, telegrams from Giolitti to Caneva, 24 and 29 October I9I I. 
captured together. ${ }^{18}$ Old men, women, and minors were also transferred to Italian penal colonies. ${ }^{19}$

After Giolitti had ordered the first deportation of Libyans in I9I I, all other deportations were ordered by the authorities in the colony. ${ }^{2 \circ}$ Indeed, the Minister of the Colonies distinguished between deportees for administrative reasons and deportees who could be tried according to what the military authorities charged them with. The latter were usually accused of threatening the security of the colony and were generally defined as "rebels". ${ }^{21}$ In I9I2, the "Commission for the Prisoners of War" suggested putting all the Libyans charged with specific crimes on trial, in order to give more "legitimacy" to the deportations. The Commission highlighted all the negative effects of deportation not only for the subjects transferred to Italy, but also for those who were in Libya, because it fuelled feelings of hostility towards the Italians. However, in I9I3, Italian authorities justified the suspension of their trial, maintaining that either they could be tried in a single trial for all the rebels at a later date, or they could be pardoned for fostering reconciliation in Libya. There was, in fact, an important fluidity in their legal status: although they were deported as an administrative measure, those subjects were considered prisoners of war. In fact, this group of deportees was seen as a potential bargaining chip in negotiations for a peace agreement.

Convict transportation began after the collective deportations of I9II-I9I2. It was the very prison rules for Libya - approved in I9I3 which established that the Libyans sentenced to penalties of more than six months' imprisonment should be transferred to Italy. In fact, the colony lacked suitable facilities for the prisons. Indeed, as late as in I93 I, the colonial government had still not built new correctional facilities, and all the spaces employed as jails were insufficient and unsuitable with regard to their "juridical, disciplinary, and sanitary needs". According to Adalgiso Ravizza, the shortage of correctional facilities in Libya had convinced the governors in Libya to command the transportation of convicts to Italy. ${ }^{22}$ Mariano D'Amelio, for his part, maintained that, since the most "fearsome

I8. See Luigi Tùccari, I governi militari della Libia (I9I I-I9I9) (Rome, I994), p. 264.

19. Because of the lack of lists of subjects who left Libya, it is not possible to indicate the number of women and minors deported to Italy.

20. One of the distinctive features of Italian colonial history was the colonial government's farreaching autonomy from the central government in Rome. See Nicola Labanca, "L'internamento coloniale italiano", in Costantino Di Sante (ed.), I campi di concentramento in Italia. Dall'internamento alla deportazione (1940-1945) (Milan, 200I), pp. 40-67, 47.

2I. See the correspondence between Bertolini, Minister of the Colonies, and the governors of Tripolitania and Cyrenaica in ACS, Ministero dell'interno, Direzione generale della pubblica sicurezza, Divisione di polizia giudiziaria, I913-1915, published in Salaheddin Hasan Sury and Giampaolo Malgeri (eds), Gli esiliati libici nel periodo coloniale (I9II-I9I6). Raccolta documentaria (Rome, 2005), pp. 50-5 I.

22. Adalgiso Ravizza, La Libia nel suo ordinamento giuridico (Padua, I93 I), p. 236. 
convicts" had been transferred to Italy, the penal transportation had facilitated the management of outdoor work for the prisoners, who were put to work in the penal agricultural colonies in Libya. ${ }^{23}$

In October I9I 5, the Ministry of the Colonies indicated to the colonial government that the transportation of convicts to Italy was not permitted by the Italian judicial system and was therefore "illegal". ${ }^{24}$ In order to curb transportation to Italy, in I9I 5 the Ministry of the Interior set out to study the possibility of confining the Arabs who had been assigned to the motherland within Libya. The Ministry of the Colonies began searching for a site in the colony where it could build penitentiaries and exile the "rebels". The colonial government in Libya immediately put a stop to the search being undertaken by the Ministry of the Colonies. ${ }^{25}$ The military authorities on the ground were well aware that control over the "fourth shore" was too weak and limited for Italy to plan new prisons and/or facilities for confinement in Libya itself.

In I9 I 5, the Minister of the Colonies had proposed to the Minister of the Interior to transfer 600 Libyans who had deserted from the native troops to Sicily, in the province of Palermo. ${ }^{26}$ Due to the war effort, there was a considerable shortage of labour in Sicily in that period. In particular, the minister thought that the Libyans could be assigned to agricultural work. The Minister of Agriculture was opposed to this labour exploitation: "it is also more dangerous the fact that in the colony, deportation is depicted as a slave trade for the farm work in Italy" ${ }^{27}$ The minister feared that the association between deportation and slavery entailed a further weakening in the international position of Italy. Therefore, Martini, who had been

23. Mariano D’Amelio, "Di alcuni caratteri della legislazione penale in Libia”, Scuola Positiva, I-2 (I9I4), p. 20. The first agricultural penitentiary colonies were established in Libya in I9 I 5 , when some convicts were sent to the experimental field in Sidi Mesri, in the neighbourhood of Tripoli. Later, in 1923, the penal colony in Sghedeida, twelve kilometres from Tripoli, was founded. Two other colonies in Cyrenaica, in Coefia and Berka, were established in 1919 and 1923 respectively. See Ravizza, La Libia nel suo ordinamento giuridico, pp. 240-246. Adalgiso Ravizza and Mariano D'Amelio were prominent jurists who were designated judges in Libya and in Eritrea.

24. Telegram from the Ministry of the Colonies to the Governor of Tripolitania and Cyrenaica, 3 I October 1915, in Archivio storico diplomatico del Ministero affari esteri, Archivio storico del Ministero dell'Africa Italiana [hereafter ASDMAE, ASMAI], folder I I 2/2, quoted in Bernini, "Documenti sulla repressione italiana in Libia", pp. I42-I43.

25. Ibid., p. I 50.

26. The reports on this issue do not specify to which type of facility (penitentiary, penal colony, or other) those subjects would be transferred.

27. In Italian: "è anche più pericoloso che in colonia la deportazione sia rappresentata come una tratta di schiavi per la lavorazione delle terre in Italia". Quote from the telegram from the Ministry of Agriculture to the General Direction for Public Security, 6 June I9I s, in ACS, Ministero dell'interno, Direzione generale della pubblica sicurezza, Divisione polizia giudiziaria [hereafter MI, DGPS, DPG], I913-1915, folder 69, in Sury and Malgeri, Gli esiliati libici nel periodo coloniale (I9II-I9I6), p. 30. 
Governor of Eritrea from I 897 to I907, tried to transfer the 600 Libyans to that colony and proposed employing them in the construction of railways. Due to a large number of Eritrean workers employed as askari (i.e. native soldier) in Libya, there was also a shortage of labour in Eritrea. Cerrina Feroni, governor of the colony, noted that the presence of the Libyans in Eritrea would be troublesome for their surveillance and incur costs owing to the need to build barracks in the penal colony in Assab. In conclusion, he maintained that it was easier to arrange for their accommodation in Italy.

Also, in I9I5, the deportees became "captives" (ostaggi): Tassoni, Governor of Tripolitania, banned the terms "deportations", "confinements", and other similar words from the official records concerning the forced removal of Libyans to Italy. According to Tassoni, the term "captives" did not provoke "any resentment from the native population against the government" ${ }^{28}$ In fact, the Italian government actually intended to use the deportees as hostages: in I9I6, the Minister of the Colonies bore down on the most prominent Libyan leaders confined in Italy to secure the release of Italian prisoners held by the enemy. ${ }^{29}$ During World War I, Libya was a country "in the grip of anarchy", as Giovanni Ameglio, then Governor of Tripolitania, reported in 1917. Economic conditions in the colony were disastrous, and a significant part of the Libyan population lived in destitute circumstances. From the beginning of 1914, with Turkish support, the Libyan anti-colonial resistance inflicted severe defeats on the Italian army. During the "great Arabic revolt", as this period of hostilities in Libya was called, many Italian soldiers were taken prisoner. In August I9 I 5, the Italian army controlled just two cities in Libya: Tripoli and Homs.

World War I was definitely the most intense and complicated period for the deportations of Libyans to Italy. The repressive measures carried out by the Italian army intensified as the siege conditions experienced by the colonizers in Libya worsened. From I9I4 to I9I 8, deportations to Italy increased remarkably. From I9I 3 to I9I 8 , most convicts were transferred to Sicily, where 2,444 Libyan "captives" arrived in its prisons and penal colonies, and 5,000 askaris were confined in the province of Syracuse. ${ }^{30}$ During World War I, the Italian authorities ordered deportation from Libya as an administrative measure and for political reasons, the transportation of

28. In Italian: "nella popolazione indigena risentimento alcuno contro il Governo". Letter from the Governor of Tripolitania, Tassoni, to the Ministry of the Colonies, Tripoli, 28 June 1915 , in ibid., p. 32 .

29. Tùccari, I governi militari della Libia, p. 265.

30. Colonial powers used the term askaris to refer to those African soldiers who fought in their armies in Africa. The Libyan askaris were transferred to Floridia and Canicattini Bagni after they had started to defect in Tripolitania. See Del Boca, Gli italiani in Libia, I, pp. 300-301. Concerning the deportation of Libyans in Sicily, see Francesca Di Pasquale, "I deportati libici in Sicilia (I9I II933)", in Carla Ghezzi and Salaheddin Hasan Sury (eds), Terzo convegno sugli esiliati libici nel periodo coloniale (Rome, 2005), pp. I37-I 47. 
convicts who had already been incarcerated within the prisons of the colony, and even the transfer of "lunatics", to be "treated" in psychiatric hospitals in the motherland. ${ }^{3 \mathrm{I}}$

Although the flow of deportations and transportation to Italy continually increased from i9I I to I9I8, peaking during World War I, on several occasions the measure was considered counterproductive owing to its political implications in Libya. Italian authorities tried endlessly to find a balance between the need for military control of the colony and the goals of reconciliation with their Libyan counterparts. On the one hand, authorities in Italy tried to restrict the transfers to Italy, while, on the other, in Libya, military and civil governors insisted on their prolongation in order to allow them to continue applying the measure. On the whole, until the beginning of the Fascist government, the "men on the spot" prevailed and military considerations triumphed over political considerations.

The flow of convicts to the metropole was directly connected to the fact that the Italian army's control over Libyan territory was weak. When its control over the colony and its population increased, the forced removals decreased. The turning point for this shift was the so-called pacification of Libya enacted by the Fascist government from 1922. This was the recourse to very cruel repressive practices in order to permanently crush the resistance movement. In particular, in 1930-193I, Lieutenant Governor Rodolfo Graziani and Governor Pietro Badoglio ordered the confinement of the whole nomadic and semi-nomadic population of Cyrenaica, to be held in twenty concentration camps in the Sirtica region. ${ }^{32}$ The main goal of the camps was to interrupt the resistance movement's support network among the population. All the camps were finally closed in I934. Scholars estimate that the number of Libyan prisoners in the camps was around I00,000-I 20,000, and that during their internment the death toll was as high as 40,000 to $48,000.33$

31. See the following records: the report by G. Girardi entitled Sulle condizioni degli Stabilimenti carcerari al 30 gingno 1916 e sul lavoro dei detenuti, in ACS, Ministero della giustizia, Direzione generale degli istituti di prevenzione e di pena, Studi per la riforma penitenziaria, folder I, file 3 and Prospetto degli stabilimenti penali al 9 febbraio 1915 , in ibid., folder 2, file 6. Further data regarding the transfer of "lunatics" to Italy during World War I can be found in Archivio di Stato di Siracusa, Prefettura, I916-1917, folder 2332, file "Ministero delle Colonie, trasporto dementi arabi. Esercizio I916-I7". As in the majority of other colonial contexts, in Libya the concept of mental illness was closely connected to the cultural parameters of the colonizers and, more specifically, to the necessity of building a society based on the clear racial separation between "black" and "whites".

32. Cyrenaica was de facto governed by the Senussi brotherhood, the religious and political organization leading the resistance movement against the colonizer.

33. On the camps in Libya see Labanca, "L'internamento coloniale italiano"; Gustavo Ottolenghi (ed.), Gli italiani e il colonialismo. I campi di detenzione italiani in Africa (Milan, 1997); and Giorgio Rochat, Le guerre italiane in Libia e in Etiopia dal I 896 al 1939 (Udine, 2009). 
The adoption of this brutal "scorched-earth policy" in Libya also marked the end of the policy of collective removal to Italy. During the Fascist era, only a few dozen Libyan notables were confined in Italy. The policy of exiling notables lay in between the ruthless repression carried out in Libya by the Fascist regime and the need to keep channels of negotiation open with exponents from elite Libyan circles. In particular, in 1930, the government in Cyrenaica ordered the deportation of thirty-one zawia chiefs and of Hassan Reda es-Senussi, grandson of the Chief of the Senussi brotherhood. ${ }^{34}$ In 1927, police rules encoded the confinement (confino) of native citizens. ${ }^{35}$ In particular, it established the confinement in a place of the colony or in a municipality in Italy of those who had been "cautioned or those who had committed or clearly shown the intention of committing acts to subvert" the rules and security of the colony. ${ }^{36}$ It is noteworthy that the Fascist government employed the confino to banish both Libyan and Italian opponents and supposed opponents.

\section{LIB YAN DEPORTEES IN ITALY}

In I9I I-I9I 2, during the collective deportations that followed the Shara alShatt revolt, Libyans were initially transferred to penal colonies on the islands of Ustica and Tremiti, and subsequently also to the penal colonies on the islands of Favignana and Ponza, and to the military penitentiary in Gaeta. After this first phase, deportees who had already been sentenced in Libya were also transported to many other Italian prisons. Below is a map illustrating the twenty-one places to which Libyans were confined during the colonial era.

In broad terms, the prisoners subject to administrative measures were transferred to penal colonies, as were political opponents (or supposed political opponents). The detainees already imprisoned in the colony were sent to the prisons. However, this distinction was not very clear, because some of the Libyan notables, removed for political reasons and without trial, were also sent to prison. During the collective deportations in I9I I-I9I 2, the majority of those deported from Tripoli were sent to the penal colonies on Ustica and Tremiti, and those from Benghazi, Derna, and Homs to Gaeta and Favignana. ${ }^{37}$ The Libyans were transferred, in fact, to the colonie coatti, i.e. penal colonies, where they were subject to the domicilio coatto, an administrative measure and "preventive" tool for public order that had been in force in Italy since I863. In this respect, their status was the same as that of the

34. The zawia were the political, economic, and social centres constituting the Senussi brotherhood's network in Cyrenaica.

35. These rules were approved by Royal Decree, 8 May 1927, n. 884 . See, in particular, articles I 8 I-I 86. On this topic, see also Ravizza, La Libia nel suo ordinamento giuridico, pp. 106-107.

36. In Italian "ammoniti o che abbiano commesso o manifestato il deliberato proposito di commettere atti diretti a sovvertire".

37. Tùccari, I governi militari della Libia, p. 264. 


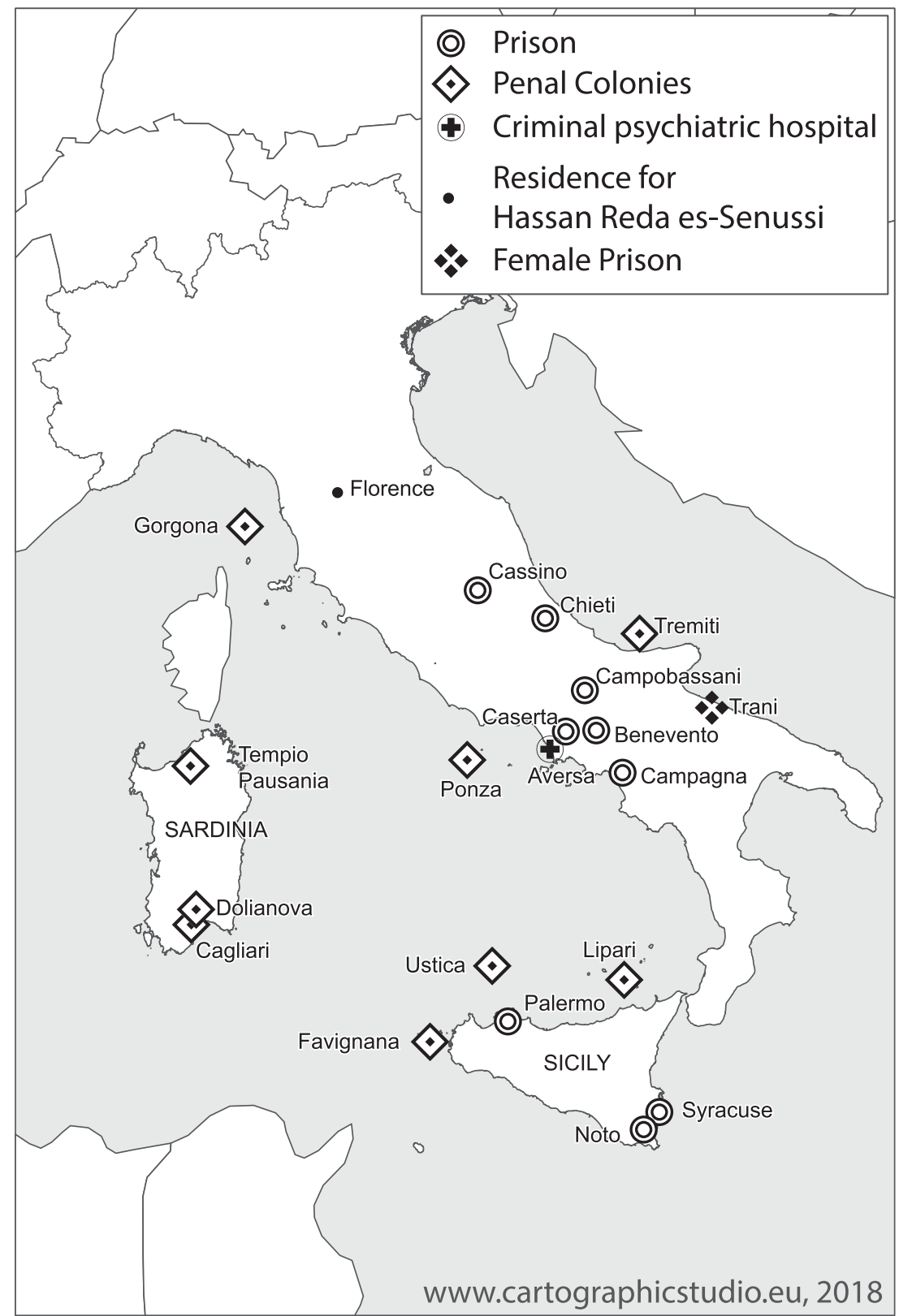

Figure I. A map of the places of deportation of Libyans in Italy.

Data deduced from ASDMAE, ASMAI, vol. II, folders: I I 2/I, I I 2/2, I 4I/I; Francesco Sulpizi and Salaheddin Hasan Sury (eds), Primo convegno sugli esiliati libici nel periodo coloniale (Rome and Tripoli, 2002); Sulpizi and Sury, Secondo convegno sugli esiliati libici; Ghezzi and Sury, Terzo convegno sugli esiliati libici. 
Italian "undesirables", such as vagrants, the "indolent", as well as political opponents. Nevertheless, for the convicts, in terms of penal regime there was no significant difference between colonie coatti and prisons. ${ }^{38}$

As the map shows, all the places to which the Italian authorities transferred the Libyans, except for Gorgona and Florence, were located in the south of Italy. One can hypothesize that this choice was the result of the link made by the Italian authorities between southern citizens and "Arabic" citizens. As already highlighted by the literature, the policies implemented in the southern regions in the decades after Italian unification were largely influenced by an "oriental" view of the southern population, who were sometimes considered to be similar to African subjects. ${ }^{39}$ However, before becoming the place to which Libyans were transferred, southern Italy had already been designated the favoured territory for the establishment of penal facilities. Penitentiary policy enacted by the first Italian governments located in Sicily five of Italy's eight penal colonies. ${ }^{40}$ Thereafter, around the end of the nineteenth century, Sardinia became the preferred site for instituting penitentiary agricultural colonies. ${ }^{4 \mathrm{I}}$ At the turn of the twentieth century, the ruling classes chose southern regions for the development of penal sites as a result of a combination of considerations: the isolation of the places selected; the intention to colonize those parts of the country that were considered "virgin" and "wild", through penitentiary agricultural colonization; and, finally, the racialized vision of the southern populations, to which I have already referred. However, Sicily's proximity to the Libyan coast also played a role in the decision to transfer the majority of Libyans to this region. In particular, during World War I, the Italian authorities arranged the flow of deportees as follows: they were transferred first to Syracuse and, afterwards, male adults were destined for Favignana, "insanes" for Aversa (Caserta, Campania region), minors for Noto (Syracuse), and women for the female penitentiary in Trani (Bari, Puglia region)..$^{42}$

38. Daniela Fozzi, "Una 'specialità italiana'. Le colonie coatte nel Regno d'Italia”, in Mario Da Passano (ed.), Le colonie penali nell'Europa dell'Ottocento (Rome, 2004), pp. 2 I 5-290.

39. See, among others, John Dickie, Darkest Italy: The Nation and Stereotypes of the Mezzogiorno, I860-I900 (New York, I999); Silvana Patriarca, Italianità. La costruzione del carattere nazionale (Rome and Bari, 2010); Jane Schneider (ed.), Italy's "Southern Question": Orientalism in One Country (Oxford and New York, 1998).

40. Di Pasquale, "I deportati libici in Sicilia (I9I I-I933)", p. I42.

4I. On the Sardinian penal colonies, see Franca Mele, "L'Asinara e le colonie penali in Sardegna. Un'isola penitenziaria?", in Da Passano, Le colonie penali nell'Europa dell'Ottocento, pp. I89-2 I 2; Vittorio Gazale and Stefano A. Tedde (eds), Le carte liberate. Viaggio negli archivi e nei luoghi delle colonie penali della Sardegna (Sassari, 2016).

42. See Prospetto degli stabilimenti penali al 9 febbraio 1915 , in folder 2, file 6 in ACS, Ministero della giustizia, Direzione generale degli istituti di prevenzione e di pena, Studi per la riforma penitenziaria and Archivio di Stato di Siracusa, Prefettura, I916-1917, folder 2332, file "Ministero delle Colonie, trasporto dementi arabi. Esercizio 1916-17". 


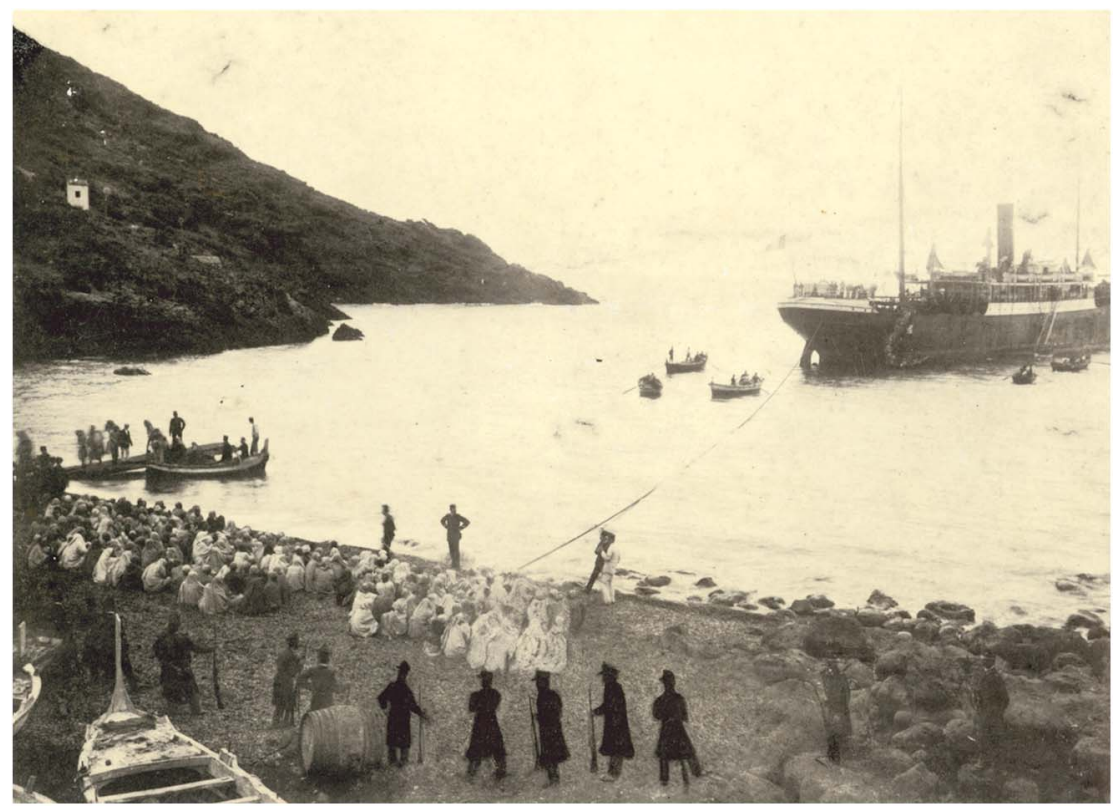

Figure 2. Arrival of Libyan deportees on Ustica, on board the steamship "Rumania", 29 October I9I I. The five guards in the foreground of the picture have been retouched by a pencil, under unknown circumstances. The Archive of the "Centro Studi Isola di Ustica" received the picture in this condition.

Archive of the "Centro Studi e Documentazione Isola di Ustica". Used by permission.

The conquest of Libya and the extensive propaganda which supported the colonial invasion contributed to developing a new national consciousness however. The colonial occupation triggered a unifying process, attenuating the regional and gender divisions that had prevailed throughout the first decades of Italian history after unification. At the same time, this process was fostered by the spread of a feeling of identity that put the Italian "race" in opposition to other "races". Therefore, the social, cultural, and gender hierarchies turned into a colonial and racist hierarchy that opposed the "white" Italian to the "black" "Arab". ${ }^{43}$ As early as I9I I, with the arrival of the Libyan deportees in Italy the majority of the population shared a sense of the "innate" superiority of Europeans over Africans. In most cases, the local communities refused to accept the Libyans who arrived. The sense of hostility towards them was also fuelled by the fact that the Libyan deportees were considered enemies

43. Lucia Re notes that the Libyan war fostered the unification of Italians by displacing racism from inside to outside the body of the nation and its people. See Lucia Re, "Italians and the Invention of Race: The Poetics and Politics of Difference in the Struggle over Libya, 1890-1913", California Italian Studies, I:I (2010), pp. I-58, 6. 
who had massacred Italian soldiers. ${ }^{44}$ However, on the small islands where the first Libyan prisoners were confined, a reversal of roles occurred, and the local population considered the colonized peoples deported to those penal colonies as "invaders".

The population of Ustica, in particular, strongly opposed the arrival of the Libyans, and members of the city council resigned in protest. Certainly, the presence of Libyans in Italy often aggravated the unstable political and economic balance on the islands on which they were confined. ${ }^{45}$ The sanitary situation was particularly critical. Those deported to Ustica, who were often carriers of cholera, died in large numbers, also due to the frigid temperatures and the overcrowding at the barracks where they lived. ${ }^{46}$ Some infectious diseases also spread among the employees of the penal colony and the local population. The problems connected with sanitary conditions were the main reason behind the protest among Ustica's citizens. However, the way in which they expressed their discomfort denoted a racist view of Libyan prisoners, who were described as "sickening individuals and plagued by thousands of infectious diseases", and as "the race considered as a vehicle of infection". ${ }^{47}$ In the meantime, from I9 I I to I9 I 2, a large number of deportees died from disease and from the conditions of their imprisonment: in Ustica, I 27 out of 900 Libyans died, which is about seventeen per cent of those who were originally transferred to that penal colony; on the islands of Tremiti, about a third of Libyans died, i.e. 437 out of I,366 deportees. ${ }^{48}$ In I9I 2 , one of the physicians employed in the penal colony in Ustica asked for some of the barracks used for the Libyans to be closed, as they "must not be considered as shelters for human beings". ${ }^{49}$

Even journalists who - circumventing government censorship ${ }^{50}-$ denounced the conditions under which the deportees were held in the

44. Tùccari, I governi militari della Libia, p. 265. See also telegram from police headquarters in Palermo to the Prefect in Palermo, 7 January 19I 2, in Archivio di Stato di Palermo (hereafter ASPa), Prefettura, Gabinetto, folder I 4 .

45. Francesca Di Pasquale, "I libici nella colonia penale di Ustica (I9I I-I9I 2)", in Sulpizi and Sury, Primo convegno su gli esiliati libici nel periodo coloniale, pp. I I 5-I 23, I 2 I-I 22.

46. Ibid., pp. I I8-i I 9 .

47. In Italian "esseri nauseabondi ed infestati da mille malattie infettive"; "la razza considerata veicolo di infezione"; "devono essere esclusi dal numero dei rifugi per esseri umani”. Quotes from a letter by a group of Ustica citizens sent to the Prefect in Palermo, 29 November I 9 I I, in ASPa, Prefettura, folder 458 .

48. On the death rate in Ustica see ibid., p. i 7 ; for the Tremiti islands see Claudio Moffa, "I deportati libici alle Tremiti dopo la rivolta di Sciara Sciatt", in Fonti e problemi della politica coloniale italiana, pp. $258-286$.

49. See the letter from the Mayor in Ustica, Bonura, sent to the Prefect in Palermo, 9 June 19 I 5 , in ASPa, Prefettura, Archivio Generale, folder 205.

50. In November I 9I I, the government prohibited journalists from visiting the Libyan deportees in the Italian penal colonies. With regard to Ustica, see the telegram from the Ministry of Interior to the Prefect of Palermo, 2 November I 9 I I, in ASPa, Prefettura, Gabinetto, folder I 2. 


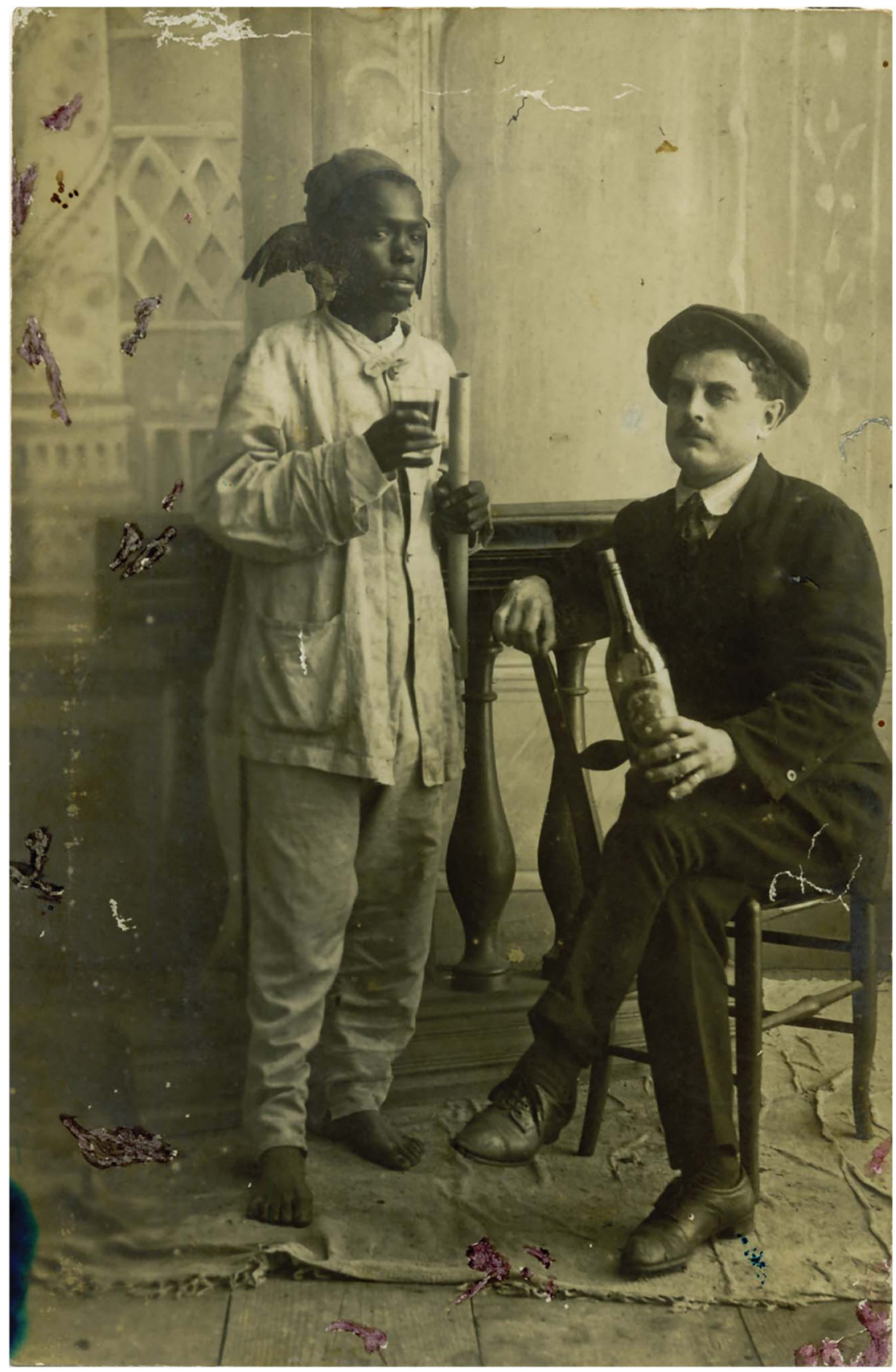

Figure 3. Photographer Giuseppe Barraco, from Ustica, with a Libyan deportee. The picture depicts the "black" servant, barefoot, and the "white" master in a typical colonial pose. Archive of the "Centro Studi e Documentazione Isola di Ustica". Used by permission. 
penal colonies adopted at best an exotic language to describe the Libyans; in most cases, they were explicitly racist. ${ }^{\text {sI }}$ The language adopted by the socialist journalist Paolo Valera, a strong opponent of the colonial venture, is particularly remarkable. In I9I2, he claimed, the people confined on Ponza Island were "muzzy", "apathetic, glassy-eyed", and showed an "idiotic" attitude. ${ }^{52}$ However, it is in his description of women that Valera shared the commonest conceptions of colonial racism towards the colonized populations. Valera wrote:

Even here, the women who arrived and who were convoyed by the policemen and by the Carabinieri are, for the most part, ugly. Among [a group of about] fifty [females], we saw only three or four young women of a true Greek and sound beauty. One in particular aroused [great] admiration: she is blonde, diaphanous, with large, sparkling eyes a mouth made for kissing..$^{53}$

Disparaged and reduced to objects of sexual desire, the women of the colonized population were at the crossing of several tensions within colonial societies. On the one hand, their control was considered essential for their role as mothers; on the other, the colonial government tried to keep under its control the sexual relations between "white" men and "black" women, worrying that the ruling "race" might "mingle" and, therefore, be "tainted" with the colonized. ${ }^{54}$

At the beginning of the twentieth century, this racist gaze was also fuelled by "scientific" discourse on human "races" based on the theses of the Positivist School. Colonial expansion had opened up a huge terrain for examination, classification, and investigation by criminal anthropologists. Libyans in Italy were the "other" at home: Africa within Italy's national boundaries. Their presence aroused the interest of physicians, criminologists, and anthropologists. It offered a priceless opportunity to study the deportees' physical traits, in order to observe the "characteristics" of the Libyan population and their supposed inclination to crime. In the Libyan colony, in I 9 1 2, a service for the identification and registration of detainees by means of photographs and dactyloscopy (i.e. fingerprint identification)

5r. See, for example, the article by Marino, entitled "Gli arabi prigionieri s'adattano al nuovo regime", published in Giornale di Sicilia, 7 November I9I I.

52. In Italian: "istupiditi"; "apatici, con gli occhi imbambolati"; "il loro atteggiamento è dell'ebete”, in Paolo Valera, “'Stazione sanitaria'. Gli arabi espulsi dal loro paese”, Avanti!', Is January I9I2, published in Sury and Malgeri, Gli esiliati libici nel periodo coloniale (I9III9I6), p. 45 .

53. In Italian: "Anche qui le donne arrivate e scortate dai questurini e dai carabinieri sono in maggioranza brutte. Fra una cinquantina non si sono vedute che tre o quattro giovanette di una vera bellezza greca e sana. Una fra tutte ha sollevato l'ammirazione: bionda, diafana, con gli occhioni pieni di faville e una bocca fatta per i baci”, in ibid.

54. For a general overview of this topic, see Frederick Cooper and Ann L. Stoler (eds), Tensions of Empire: Colonial Cultures in a Bourgeois World (Berkeley, CA, I997). 
was established. 55 Its purpose was to acquire "knowledge of the population of the new colony, knowledge that will be useful both from a scientific and from a practical standpoint". ${ }^{56}$

In I915, Emanuele Mirabella, who was in charge of the health service in the penal colony in Favignana (and who had been a physician at the criminal psychiatric hospital in Aversa), examined the Libyans there. He carried out a study in order to compare their characteristics with those of ordinary Italian citizens and criminals. He highlighted "the degenerative features typical of this new population" and concluded that Libyans were inferior also to Italian criminals. After his study, Mirabella wrote a book about Libyan deportees in Favignana. ${ }^{57}$ He dedicated the book to Enrico Ferri, one of the most prominent exponents of Italian criminal anthropology.

In that same year, about 5,000 Libyans were moved to Sicily. They were askaris, whom the Italian authorities transferred to the island along with their families in order to avoid them joining the resistance movement. Umberto Grabbi, an expert on exotic diseases and professor at the University of Messina, and Nello Piccioni of the National Museum of Anthropology and Ethnology in Florence studied this large group of Libyans, who had been relocated to two small villages in Sicily, namely Floridia and Canicattini Bagni (Syracuse). ${ }^{58}$

Starting from World War I, a number of "lunatics" were also transferred by the Italian authorities. ${ }^{59}$ Clearly, their transfer to Italy had no punitive goal, nor was it intended to prevent the formation of rebel groups, as was the case with the deportations, the subject of the present study. Moreover, their internment in Italy reflected the interest in the mental illness of the natives expressed by the Italian government from 191 2 onwards. ${ }^{60}$ What deserves to be highlighted, instead, is that deportees, askaris, and "lunatics" were relevant for criminologists and anthropologists in the same way, according to a view that subsumed them within the same category, based on their "racial" identity. Since there was no mental asylum in Libya, the "lunatics" were interned in the criminal psychiatric

55. D’Amelio, "Di alcuni caratteri della legislazione penale in Libia”, p. 2 I.

56. See Mary Gibson, Born to Crime: Cesare Lombroso and the Origins of Biological Criminology (London, 2002), p. 148.

57. Emanuele Mirabella, I caratteri antropologici dei Libici in rapporto ai normali ed ai delinquenti italiani (Rome, I915).

58. Bernini, "Documenti sulla repressione italiana in Libia", pp. I53-157.

59. Prospetto degli stabilimenti penali al 9 febbraio 1915 , in folder 2, file 6 in ACS, Ministero della giustizia, Direzione generale degli istituti di prevenzione e di pena, Studi per la riforma penitenziaria and Archivio di Stato di Siracusa, Prefettura, 1916-1917, folder 2332, file "Ministero delle Colonie, trasporto dementi arabi. Esercizio r916-17". Marianna Scarfone has analysed the history of the "lunatics" transferred to the Psychiatric Hospital in Palermo in the I930s: "La psichiatria coloniale italiana. Teorie, pratiche, protagonisti, istituzioni I906-I952" (Ph.D., Ca' Foscari University, 20I4), pp. 3I I-332.

6o. Ibid., p. 237. 
hospital in Aversa. Mohamed ben Mohamed Behera, from Benghazi, was one of them. He arrived in Aversa on 26 June I9I4 and died within a year, on I 8 June I91 5. During his internment, his brother, who was being confined in Favignana during the same period, wrote many letters to the director of the hospital in Aversa asking after Behera's health. ${ }^{61}$ His supposed mental illness was connected to his sexual behaviour. The police in Benghazi had reported that Behera had exhibited "inappropriate" sexual behaviour - he had approached male minors, a female Jewish minor, and a Maltese girl. ${ }^{62}$ As we have already observed, the sexual behaviour of both colonizers and the colonized was a "minefield" for colonial relationships. ${ }^{63}$ Even within Italy, the terrain of sexuality endangered Italian dominion over North African people.

Certainly, the deportation of Libyans to Italy was a demonstration of strength over the colonized. At the same time, the presence of the colonized in the motherland in some respects overturned the "colonial situation", ${ }_{4}$ undermining the relationship of power between Italians and North Africans. In particular, in Italy social relationships between the colonizers and the colonized were governed by rules different from the set of social norms in force in the colony. In particular, in Italy the social norms that established colonial relations and the hierarchy of colonizers over the colonized risked being subverted. This had the potential to undermine Italian prestige. And this was what happened in at least some situations involving relations between "black" men and "white" women. The presence of askaris in Sicily caused conflict with the local population. Indeed, the main reason why the Italian authorities decided to transfer Libyan soldiers with their families was because askaris had established "overly intimate" relationships with Sicilian women. ${ }^{65}$

During the Fascist period, Italian authorities had greater regard for the Libyan notables exiled in Italy. One can plausibly hypothesize that the Fascist government in Libya tried to secure itself potential interlocutors within Arab elite circles with whom it could establish a dialogue after military operations ceased. The main difference between exile and deportation concerned the living conditions guaranteed to the two groups of Arabs transferred to Italy. The Libyan exiles enjoyed "favourable" treatment, which made their stay in

6r. During World War I, there was an exchange of letters among the deportees in Italy. They exchanged information, both personal and about their relatives; they reported on the treatment received in the penal colonies or in prison; and they gave instructions regarding their property or affairs in Libya. See Luciano Nisticò, "Relegati libici in Italia. Un aspetto poco noto della conquista coloniale", Islàm Storia e Civiltà, 4 (1989), pp. 27 5-285.

62. See the personal file of Mohamed ben Mohamed Behera in Archivio storico dell'Ospedale psichiatrico giudiziario di Aversa, Aversa (Caserta).

63. Ann L. Stoler, Carnal Knowledge and Imperial Power: Race and the Intimate in Colonial Rule (Berkeley, CA [etc.], 2010).

64. Georges Balandier, "La situation Colonial: Approche Théorique", Cabiers Internationaux de Sociologie, I I (195 I), pp. 44-79.

65. Bernini, "Documenti sulla repressione italiana in Libia", pp. I $54^{-1} 55$. 
Italy less burdensome than that of the majority of the other deportees. In particular, during their exile in Ustica, the zawia chiefs received a daily food allowance of five lire. Hassan Reda es-Senussi's exile was even more "comfortable". This notable had made a deal with the Italian government in I 929 and had accepted the colonizer's peace terms. Despite these negotiations, Graziani ordered his confinement in Italy, though he allowed him to move together with his wife, his daughter, and two "servants". Furthermore, the Italian government provided a remarkable allowance to Hassan, amounting to some 4,000 lire per month. ${ }^{66}$

The story of Hassan Reda es-Senussi in Italy exemplifies how the presence of natives in Italy might break the colonial order. He was exiled to Ustica in September 1930 and then, in June $193 \mathrm{I}$, transferred to the Tremiti islands, owing to his "excessive familiarity" with many families in Ustica. In particular, a "distinguished person" from the island did not hesitate to promise his daughter to the Libyan notable, after he had asked to marry her - "even if he knew that Hassan was married with children" - but only on condition that es-Senussi provide a dowry of half a million lire. In the small Tremiti archipelago, some inhabitants who knew about his economic resources conned him, convincing him to spend more than he owned. In I934, when Marshal Italo Balbo (Governor of Libya at the time) was trying to weave political alliances on Italy's "fourth shore" after the cessation of military operations, Hassan declared himself willing to negotiate with the Grand Senussi on behalf of the Italian government. In that same year, Hassan moved to Florence, where he died two years later. ${ }^{67}$ On account of his political influence, Hassan was in the "grey area" between natives and colonizers. More generally, his experience in Italy had explicitly revealed the incompatibility of his status with the colonial hierarchy.

\section{CONCLUSION}

Italy's recourse to collective deportation was symptomatic of its weakness: the military authorities in the colony needed to expel "enemies" or potential "enemies" in order to reduce the threat posed by the resistance movement. This was what happened in particular from I 9 I until World War I. ${ }^{68}$ During the Fascist era, collective deportations ended and the regime chose to confine the nomadic and semi-nomadic populations of Cyrenaica in concentration camps in the Libyan desert. Italy deported Libyans to the motherland and not to its other colonial possessions. This was due to a combination of factors.

66. Eleonora Insalaco, "Confino politico nell'isola di Ustica di trentuno capi zavia e del senusso Hassan er-Reda es-Senussi dal settembre 1930", in Sulpizi and Sury, Secondo convegno su gli esiliati libici nel periodo coloniale, p. I24.

67. Ibid., pp. I $25-\mathrm{I} 26$.

68. Bernini, "Documenti sulla repressione italiana in Libia”, p. I23. 
Firstly, Italy did not have a large colonial empire with a choice of convict destinations. Secondly, Libya was much closer to Italy than to Italy's other possessions in East Africa. Thirdly, the "colonial" view of certain parts of Italy prevalent among the political authorities, and in particular concerning southern regions and the prison-islands, influenced the decision to designate Italy the favoured territory for the establishment of penal facilities. Lastly, throughout the Liberal period, Italian officials were opposed to the transfer of Libyans from one colony to another (as was the case with the removal of the askaris from Libya to Eritrea) and to their confinement within Libya.

Within the Italian colonial system, the deportation and transportation of convicts had exclusively punitive or preventive goals. Italy did not deport colonized peoples for labour purposes. On the contrary, the Italian authorities made every effort to dispel the association between punishment and labour exploitation. This concern arose from the weak political equilibrium that characterized the development of Italy's colonial venture, owing to the confrontation with other colonial powers but also to opposition within the colonial territories.

The peculiarity of the Italian case can also be analysed within a more general framework, which takes into consideration the imperial landscape in the nineteenth and twentieth centuries. The weakness of Italy as a colonial power arose from its position as a latecomer in the European imperial context. Italy did not embark on its colonial venture until the other main colonial powers had already become well established. In particular, in the final decades of the nineteenth century, when Italy took its first steps in acquiring its first colonial possession, Eritrea, slavery had already been abolished in most European colonies in Africa and Asia. Furthermore, Italy had no recent history of involvement in slavery. ${ }^{69}$ All of these factors contribute to explaining the lack of connection between deportation, transportation, and forced labour in the Italian case.

With regard to the encounter between Italians and Libyans, this occasioned one of the first cases of "interracial" relationships in contemporary Italy. Italians saw Libyans through the lens of the colonial and racial hierarchy. The relationship between Libyans and Italians was marked by "new" codes in comparison with those that had been in force for centuries in the Mediterranean area and that had been characterized by uninterrupted encounters and exchanges between the two populations. Perhaps the most interesting feature of the presence of Libyan deportees in Italy concerns the manner in which the encounter with Italian society disrupted the social norms that were supposed to govern colonial relationships. This gave rise to a number of new social dynamics. Above all, it shows clearly that the history of these movements connects Libya and Italy within one and the same framework. As the case of deportation again highlights, it is impractical to elaborate a historical

69. Anderson and Maxwell-Stewart, "Convict Labour and the Western Empires, I4I 5-1954", p. 2 I8. 
analysis based on any rigid division between the colony and the motherland. As Sanjay Subrahmanyam would put it, it is much more fruitful to consider the histories of the two shores of the Mediterranean as "connected histories", where the connectedness does not erase regional, social, and cultural differences, but instead emerges from it. ${ }^{70}$ 